\title{
Sustainable Development of Universities Based on Their Intellectual Capital
}

\author{
Pavel Novgorodov*
}

\author{
Novosibirsk State University of Economics and Management, Novosibirsk, Russia \\ *Corresponding author. Email: novg78@yandex.ru
}

\begin{abstract}
The article offers a new perspective on the sustainable development of universities considering the experience of the Covid-19 pandemic. Methodological aspects of cost assessment of the university intellectual capital as an alternative approach to the assessment of university activities are studied. The advantages of the cost assessment in comparison with the university ratings are substantiated, including for the purposes of university management to ensure its sustainable development. Algorithms for the application of intellectual capital assessment methods based on Market Capitalization Methods (MCM) and Return-On-Assets Methods (ROA) are described. The application of various methods for different types of countries, with market and socially-oriented education systems, is justified. The conclusion was made that it is necessary to develop and apply cost indicators for the intellectual capital assessment in combination with ratings and other existing metrics used for the evaluation of university activities with a view to clarifying strategies and programs for the development of universities, as well as the feasibility of switching to Value Based Management (VBM).
\end{abstract}

Keywords: intellectual capital, ratings, Value Based University Management, methods of value estimation.

\section{INTRODUCTION}

The Covid-19 pandemic has significantly changed the way universities operate, although many researchers claim that it has only accelerated the processes that were already occurring in the education system before the pandemic. This includes online courses and the development of other distance forms of education, as well as the use of digital technologies in the university management.

During the pandemic, one of the strong challenges was the maintenance of the quality of education. It is obvious that distance technologies have both their advantages and disadvantages, and they differ significantly depending on a particular university, and a particular type of educational program. Universities, heavily depending on the availability of physical assets - equipment, laboratories, experienced the most significant problems during this period.

The deteriorating quality of education, or even the expectation of such deterioration, initiated a wave of students' claims to reduce the cost of tuition at those universities where the students pay full or partial tuition fees. In case the university found these claims to be justified, the tuition fees were reduced, but as a result the universities had to search for alternative funding sources (e.g. obtaining direct state aid) and had to reduce costs - primarily investment costs, as well as personnel costs. This predictably caused a stressful situation for the founders, management and university staff.

Thus, the pandemic has had a serious impact on the key performance indicators of universities: the quality of education, the interaction with students, infrastructure, finances, investments, personnel policy, and highlighted the challenges of university sustainable development in both practical and methodological terms. Universities have acknowledged the need to develop a new approach to the sources of university sustainable development, new methods and indicators for evaluating their activities, including those used for "stress tests".

One of the generally recognized tools for a comprehensive assessment of the university activities are ratings: both international (primarily THE, QS, ARWU) and regional, as well as national [1]. Every year new ratings are published, the methods of existing ones are improved. For example, in 2019, Russia 
developed and presented a National Aggregated Rating [2] based on the league analysis methodology [3], which was considered as the basis of a risk-based methodology for evaluating universities, and as a major tool when making decisions on the verification and accreditation procedures.

At the same time, the objectivity of ratings as an assessment tool causes reasonable doubts [4]. Both particular methods (including the subjectivity of the assessment, since the weight of "expert opinion" in various methods can exceed $50 \%$ ) and the possibility of applying uniform criteria to universities that have significant differences in their activities [5] can be subjected to criticism.

The complexity of the university as an object of evaluation is associated with the multi-vector nature of its activities, a wide range and intangibility of its key results, a long production horizon. At the same time, the direct comparison of universities due to their specificity, differences in goals set and tasks performed is accurate only within a relatively small sampling of universities that are similar in certain parameters: such an idea is put, for example, in the U-Multirank approach [6].

Moreover, the pandemic has shown that traditional university ratings do not characterize the university's sustainability and resilience to "black swans" and the ability of the university's management to respond effectively to them [7]. In this case, sustainability is understood in a broad sense - as the ability to realize the goals and objectives of the university in case external negative factors emerge.

The importance of evaluating and comparing the results of university activities, be it the assessment by the state, society, or university management, actualizes the need to develop alternative approaches, one of which is the assessment of intellectual capital.

Intellectual capital is the key type of capital of the university and determines its competitiveness and the its ability to achieve the stated objectives in education, upbringing, research and development, "third mission", entrepreneurship, etc.

With the development of distance forms of education accelerated by the pandemic, virtualization and digitalization, and the concomitant decline in the importance of material infrastructure, intellectual capital becomes the basis for sustainable development of the university.

\section{MATERIALS AND METHODS}

The assessment of the university activities through its intellectual capital involves the identification of its structural elements. We based our analysis on the components of intellectual capital proposed by G. Roos,
S. Pike and L. Fernstrom, i.e. human, organizational and relational capital [8].

The first one is represented by knowledge, skills, experience and reputation of its employees, as well as students. The second one includes the organizational structure, educational programs, technologies, databases, as well as the issued intellectual property of the university. The third component - relational - is represented by the university system of relations with applicants, graduates, authorities, business, professional environment, etc.

All types of university capital are in a complex interaction: each element determines the development of the others and vice versa. Accordingly, to ensure the sustainability of the university, it is important to manage all elements of capital by using a wide range of tools.

The importance of organizational and relational capital for the development of the university is often underestimated. The existing methods of intellectual capital assessment are mainly related to the analysis of the quality of human capital. But it is precisely the underdevelopment of other types of capital (for example, excessive bureaucratization, unoptimized business processes, low customer orientation, imperfection of programs, poor marketing, etc.) that leads the university to the loss of its human capital, or prevents its potential from being maximized. The ability to acknowledge these problems is an important component of managing the university and its intellectual capital. This, in turn, implies a periodic assessment of intellectual capital through a system of indicators.

Currently, the assessment of the intellectual capital of universities is carried out mainly by non-financial methods [9], which are based on the determination of quantitative indicators of intellectual capital characterizing its individual elements: human, organizational and relational capital. In fact, many ratings are based on an identical approach: to form a rating, corresponding weights are assigned to various indicators to bring them to a single integral indicator.

An approach that reflects the results of the university's activities more objectively is the assessment of its intellectual capital. A higher degree of objectivity is achieved when the assessment is based on the real cash flows of the university generated by various elements of its intellectual capital.

Assessment, unlike ratings, has a number of advantages:

- correlates the result with the costs incurred to achieve it;

- makes it possible to evaluate the effectiveness of public and private financing of a single university and the higher education system as a whole; 
- to a large extent, it helps level the effect of accumulated results through the analysis of cost dynamics;

- gives the absolute (but not relative) value of the rating and its change;

- makes it possible to identify cost factors and influence them;

- provides an opportunity to use the Value Based Management Concept in relation to universities;

- the results of the assessment provide the basis for the management of the university in line with sustainable development.

It is known that the market value of a business is a recognized criterion of the organization efficiency in the commercial sphere, but its application in other areas has various limitations.

The existing methods the intellectual capital assessment are formulated in terms of three appraisal approaches: income, comparative, or market, and cost approach [10]. With a number of assumptions and limitations, most of the methods can be applied to universities. For example, the use of return-on-assets (ROA) methods in the framework of a comparative approach reveals a significant difference in the income received by universities per unit of asset (per employee, per student, per unit of infrastructure, etc.), but in the context of the university specificity (type of university, share of budget funding, region of presence, structure of students, etc.) it cannot give an unambiguous interpretation of the results as a difference in the value of the intellectual capital. This implies the need to form typological groups of universities that are similar in one way or another.

For the intellectual capital assessment of a university, several basic schemes can be proposed. They can be applied thanks to the presence of price distortions due to the significant role of the state in the field of higher education (regulation, budget financing, etc.). In case of their absence or minimal influence (this is typical, for example, for American universities and a number of other countries with a conditionally "market" system of higher education), the following algorithm can be applied based on Market Capitalization Methods (MCM):

1. The income of the university and its sources are determined from the perspective of the areas of activity (education, science, entrepreneurship, infrastructure, etc.), payers (state, organizations, and individuals).

2. The cost of the university as a legal entity is assessed through comparative (or market approach) or income approach.

3. The value of the material assets of the university (balance value) is deducted from the received value.
4. The resulting difference is interpreted as the cost of the intellectual capital of the university.

This calculation is based on the Calculated Integral Value Method proposed by T. Stewart in 1997 [11].

The use of this method assumes a fundamental opportunity to assess the market value of the university and interpret it as a sum of the book value of the property and the value of intellectual capital.

The market value of the university can be determined by different approaches and methods.

For market economies - countries where universities and colleges are the subject of purchase and sale - it is advisable to use comparative methods. At the same time, the assessment obtained can be considered a fairly reliable basis for further calculations of the value of intellectual capital.

In case of underdevelopment or absence of the market, the methods of a profitable approach can be used. At the same time, as a rule, undeveloped markets are characteristic of countries with a socially oriented system of higher education, which is characterized by "price" distortions (the income of such a system usually does not reflect the real value of the goods received and the cost calculated by the income approach will usually be lower than the market value). In this regard, the obtained estimates of the value of universities or the value of the university intellectual capital of, since it's private, will require a certain adjustment to obtain an estimate close to the market.

The assessment of the university value in sociallyoriented systems can be carried out when the state has a hypothetical objective to privatize part of universities. In this case, the problem of both value estimation and cost management will turn from a speculative one into a concrete one. Let's assume that the state has made such a decision, and it is necessary to conduct an initial assessment, to identify cost factors from the perspective of a potential investor and understand in what ways and within what period this cost can be increased in order to maximize income from privatization (a management task within the VBM approach), and then to re-evaluate and set the sale price.

Russia is characterized by an undeveloped market for the purchase and sale of universities. Although there are private universities on the market, and there were some cases when they changed their owners, nevertheless, they are isolated, and information about transactions, including the cost of purchase and sale, is not publicised. Therefore, the methods of a profitable approach will be used to assess the cost of Russian universities.

The cost of educational services in Russia is significantly lower than in many foreign countries with comparable non-financial indicators of intellectual 
capital, therefore, the application of the algorithm above to Russian universities, as a rule, gives a negative value of the cost of intellectual capital at stage 3. This, however, does not characterize the intellectual capital as such, but the degree of underfunding of the higher education system.

In this regard, within the national educational systems characterized by significant price distortions, it is possible either to change the described algorithm through adjusting the volume of cash flows to eliminate the identified distortions, or to use a fundamentally different algorithm based on Return-on-Assets Methods (ROA):

1. Typological groups of universities similar in their key parameters of activity are to be determined.

2. Cash flows of universities are to be analyzed by areas of activity and sources, if necessary, adjustments are to be made (for example, taking into account their location).

3. Cash flows are to be distributed into those generated by material capital and those generated by intellectual capital.

4. The specific indicators of university income from intellectual capital per unit of asset are to be determined.

5. The rate of return on intellectual capital is to be determined by the typological group of universities (the determination of the rate of return, in turn, is also possible through the use of several techniques).

6. The cost of the intellectual capital of the university is to be calculated.

Due to the fact that universities have a significant differentiation in size, type, location and other parameters, when using this method, it is advisable to identify clusters of similar universities and evaluate the average values within the cluster, as well as to make certain correction to the data the calculations are based on, in order to exclude factors that are not significant in terms of intellectual capital.

One of the methods of determining the market value of some types of business is to determine the specific unit value per unit of any quantitative indicator that is important for this business.

For example, this approach is used to assess the market value of companies that produce and use software. The number of users of the product is critical for assessing the market value and for different types of software, depending on the target audience, the type of market and a number of other factors, a cost indicator per customer is set as a guideline for calculating the total market value. Such approaches are used to assess the value of companies that own social networks, messengers and other software products that have a large number of users.
For companies that own real estate for lease, as well as for trading companies that own stores, an important indicator underlying the calculation of the market value of the company is the income per $1 \mathrm{~m} 2$ of rental or retail space.

Companies which business is based on knowledge (audit, consulting, legal, project companies, etc.) are expected to use the number of employees belonging to the main "production" personnel as a basic quantitative indicator. Such companies have various statistics, characterizing the total and net income or profit per employee both for individual companies and for the market on average. Significant upward deviations from the indicator's mean can be interpreted as the cost of intellectual capital.

Regarding intellectual capital, universities are close to these knowledge-based companies, therefore it is advisable to operate with income indicators (general and by areas of activity) in terms of one employee (the denominator uses both the total number of employees and by category - teachers, researchers).

The calculation of the cost of intellectual capital according to the algorithm above shows the ability of universities to raise funds through the implementation of research projects, grants, supplementary education programs (for human capital), attracting more applicants, interaction with employers, graduates, sponsors (for relational capital), increase profitability by improving the efficiency of the university's operational activities (for organizational capital) and is collectively interpreted as the cost of intellectual capital.

\section{RESULTS AND DISCUSSION}

Periodic assessment of intellectual capital makes it possible to create a system for monitoring university performance indicators by type of capital, identify factors influencing the cost and grade them according to their degree of importance. An important advantage of the assessment capital is that the financial side of the issue is taken into account: this eliminates the "solve the problem at any cost" approach. Within the framework of existing approaches to assessing the activities of universities, it is possible to record the progress in some indicators, which will be interpreted as a positive signal. However, if this progress is provided due to the excess amount of resources spent, the cost approach will make it easily noticeable. Thus, the university can avoid the situation when a "breakthrough" is being achieved at the cost of increasing the instability.

The possibility of intellectual capital assessment leads to the fundamental possibility of using Value Based Management tools for universities. The main management indicators are the dynamics of changes in the capital cost and its individual elements, specific cost indicators (per teacher, per student, etc.), as well as 
comparative assessments with other universities. In turn, this leads to a clarification of the criteria for the effectiveness of universities, the need to update their strategies and development programmes.

\section{CONCLUSION}

The assessment of intellectual capital gives a fundamentally different view of the evaluation of the activities of universities both from the position of the state, society, and management and offers a new set of university management tools.

It should be noted that the cost approach is not an exhaustive evaluation tool, rather, it serves as a supplement to the existing methods of evaluating the activities of universities, including ratings. The main methodological problem of intellectual capital assessment is a wide range of intangible effects of the activities of the university, which, as a rule, cannot be measured. These effects are in a complex relationship and manifest themselves on different time horizons. In addition, the intellectual capital of the university is a weekly structured intangible asset, which in itself creates problems in its identification for subsequent evaluation. However, the development of big data technologies, including in education, gives more and more opportunities to "capture" the components of this asset. Thus, it can be concluded that the assessment of the intellectual capital of the university has a great potential for development and application in the future.

\section{REFERENCES}

[1] A.Oborskii, A.Amerslanova. The Assessment of Russian Scientific Institutions' Intellectual Capital. Accounting. Analysis. Auditing. 6(5) (2019) pp. 80-87. DOI: https://doi.org/10.26794/2408-9303-2019-6-5-8087

[2] A. Bolotov, G. Motova, V. Navodnov, O. Ryzhakova. How to Design a National Aggregated Ranking? Vysshee obrazovanie v Rossii = Higher Education in Russia. 29(1) (2020) pp. 9-24. DOI: https:/doi.org/10.31992/0869-3617-2020-29-1-924

[3] V. Navodnov, G. Motova, O. Ryzhakova. The Method of League Analysis and Its Application in Comparing Global University Rankings and Russia's University Performance Monitoring. Voprosy obrazovaniya, Educational Studies Moscow. 3 (2019) pp. 130-151. DOI: https://doi.org/10.17323/1814-9545-2019-3-130151

[4] L. Taradina. World University Rankings: Do they influence university development and can we trust them? Bulletin of Orthodox Sacred and Tychonoff Humanities University. Series 4: Pedagogics. Psychology, 2(33) (2014) pp. 9-17. DOI: https://doi.org/10.15382/sturIV201433.9-17

[5] P. Novgorodov Efficiency of universities performance: from monitoring and ranking to intellectual capital evaluation. Upravlenets - The Manager, 9(1) (2018) pp. 48-55. DOI: https://doi.org/10.29141/2218-5003-2018-9-1-7

[6] H. F. Moed. A critical comparative analysis of five world university rankings. Scientometrics. 110 (2017) pp. 967-990. DOI: https://doi.org/10.1007/s11192-016-2212-y

[7] S. Veltri, P. Puntillo. On intellectual capital management as an evaluation criterion for university managers: a case study. Journal of Management and Governance 24 (2020) pp. 135167. DOI: https://doi.org/10.1007/s10997-01909461-5

[8] G. Roos, S. Pike, L. Fernstrom. Managing Intellectual Capital In Practice. Butterworth Heinemann, 2005, p. 19. DOI: https://doi.org/10.4324/9780080479118

[9] P. Novgorodov Valuation of Higher Education Institution's Intellectual Capital: The Issue of Methodology. Journal of New Economy. 20(1) (2019) pp. 78-94. DOI: https://doi.org/10.29141/2073-1019-2019-20-1-6.

[10] J. Häcker, D. Ernst. Financial Modeling. Palgrave Macmillan, 2017.2 DOI: https://doi.org/10.1057/978-1-137-42658-1

[11] S. Aho, S. Ståhle, P. Ståhle. A critical assessment of Stewart's CIV method. Measuring Business Excellence. 15(4) (2011) pp. 27-35. DOI: https://doi.org/10.1108/13683041111184080 